\section{Open letter to Paul Doty}

DEAR PAUL - Your recent comments on my activities (Nature 352, 183; 1991) require a brief response.

The standards of scientific investigation are the highest standards to which humans can aspire. Trying to understand the secrets hidden away in nature is a difficult and trying enterprise that requires a critical assessment of each piece of evidence and a sceptical review of every idea. The judgement of past human activities is even more demanding because there is no possibility of repetition.

You have used a leaked, confidential draft of a government report as a basis for definitive judgements about the acts of others. Neither you nor those judged have had full access to the evidence. Your judgements therefore could not have derived from the careful assessments that you yourself say that scientific evidence requires. The staff of the Office of Scientific Integrity has recognized that a fair judgement requires access to the evidence. But your judgements do not depend on complete evidence; your verdicts are, rather, based mainly on the unsubstantiated, and often refuted, allegations of one participant in events five years old.

You say that I failed traditional standards of science but you have not discussed the events with me, choosing to rely on information from others. On that basis you have enlisted in a campaign of criticism. Paul, there are a few things you should know and I would like to share.

I believe that my science - including the Weaver et al. paper - is done with rigour and criticality. But, because the issue is one of judging historical events, the only way to judge that statement is by the traditional test of science: have the data proved reliable?

For the Weaver et al. paper, the data have proved more durable than the data in most papers. No experiments of which I am aware have appeared in the literature that contradict the data of the Weaver et al. paper. In fact, there is much published evidence ${ }^{*}$ and more coming that support the paper's results in remarkable detail.

One of your statements, Paul, is unworthy of you. You charge that an "embarrassing" band was eliminated from a figure by underexposure of the image. That is plain wrong: no one consciously eliminated any band. There was a faint band that we saw in the original autoradiogram that was not visible in the published figure. That loss occurred at some indeterminate time in the publication process, as has happened to many faint bands. In any case, it was not embarrassing; its existence was not of significance to the paper, otherwise it would have been investigated further. Even if that band could be shown to represent a small expression of $\mu$ RNA in that particular hybridoma, the interpretation that the cell was making a gamma protein with idiotypic characteristics and a $V$ region like that of the transgene would not be changed. That was the issue at stake there. I urge you to go back and study this again.

I welcome your call for the highest standards in the prosecution of scientific investigations. I have supported just those values all of my scientific life and will continue to do so.

In contrast to your apparent certainty about the events of the past, I am not now convinced that I know all the answers. But I do know that I have tried to ferret out the truth and I feel that I did reasonably well because the science has stood up to the toughest test of all, the test of history.

\section{Rockefeller University,}

DAVID BALTIMORE

\section{York Avenue,}

New York

New York 10021-6399, USA

*J. clin. Invest. 79, 1044-1053 (1987): Eur. J. Immunol. 17. 399-403 (1987); Proc. natn. Acad. Sci. U.S.A. 85 3546-3550 (1988); Proc. natn. Acad. Sci. U.S.A. 86 2346-2350 (1989); int. Immunol. 3, 67-73 (1991); int Immunol. 3, 185-196 (1991).

\section{The case against}

SIR - Your leading article, "The case for the human genome" (Nature 352, 11; 1991), shows breathtaking ignorance of some historical and ethical aspects, which will be used as arguments against the genome project. The statement "Those who in the 1930 s mounted the holocaust hardly bothered to excuse themselves by reference to genetics, although the ill defined and empty doctrine of Aryan superiority may have stilled the consciences of some practitioners," is a travesty of the truth and cannot pass unchallenged. Are you not aware that it was the geneticists and related scientists of the time, including Fischer, Von Verschuer and Lenz, who provided and supported the supposed scientific foundations on which the whole philosophy was based ${ }^{1}$, and who supported its putting into practice along with their medical colleagues? It is hardly surprising that the article expresses bewilderment with present-day attitudes in Germany that are attempting to reconcile future progress with past abuses.

In dismissing the likely problems of genetic testing in relation to insurance, the leading article states: "the contention that people unlucky enough to carry identifiable genetic abnormalities should not be denied insurance on the same terms as other people begs the question why people relatively free from identifiable genetic abnormality should therefore pay more than would otherwise be necessary". Such a view totally ignores the complexity of issues involved, including third party pressures for testing for late-onset disorders, where serious problems are already arising.

Most responsible scientists are keenly aware of the ethical problems that their work may raise and are glad to see them debated and, where possible, resolved. To suggest that the ethical problems raised by the human genome project are "insubstantial" and should be "handled delicately", is to give support to those in the community who contend that scientists cannot be trusted to act responsibly on ethical issues.

PETER S. HARPER

University Hospital of Wales,

Heath Park, Cardiff CF4 4XW, UK

1. Weindling, P. Health, Race and German Politics between National Unification and Nazism, 1870-1945 (Cambridge University Press, 1989\}.

\section{On the run}

SIR - Where have the Arizonans Ronald Dorn and James Clark (Nature 352,$10 ; 1991$ ) been for the past century? Not, I trust, on the run. To find an answer to their question about the use of the term 'run' to connote a session on an instrument, one need look no further than the Oxford Dictionary. Among numerous definitions of 'run' one finds "spell of making or allowing machinery to run or continue to work", with the year 1875 given as the first documented date of the use of this particular meaning. Scientific analysis is probably just a relative newcomer to this long established terminology.

Cardiff Institute of Higher Education. Cardiff CF5 2SG UK

\section{Help wanted}

SIR - The Committee on Medical Aspects of Food Policy of the Department of Health has set up a Working Group to review the nutrition of young children during the weaning period. The working group is concerned that its deliberations should encompass all opinions in its field and invites concise written submissions based on reasoned argument and scientific data from interested parties. Submissions should be sent to me.

P. CLARKE

(Nutrition Unit)

Department of Health,

Room 541, Wellington House,

133-155 Waterloo Road,

London SE1 8UG, UK 